\title{
Church unions and their consequences in Poland
}

\author{
Antoni Mironowicz \\ Uniwersytet w Białymstoku \\ amir@uwb.edu.pl
}

\begin{abstract}
Antoni Mironowicz, Church Unions on Polish Land and Their Consequences, Elpis, 16 2014: 159-168.
Abstract: Orthodox Christians in Poland have faced numerous attempts to be forced into union with the Roman Catholic Church, ranging from the thirteenth to the twentieth century. The first attempt at a union between the Roman Catholic Church and the Orthodox Church took place as early as the mid-thirteenth century. Another attempt at forcing the Orthodox Church into union with Rome took place during the reign of Ladislaŭ II Yagiello. The problem of church union returned in the reign of Alexander the Yagiellonian. When Ivan III rejected all projects for bringing the Florence such a union into practice, discussion on church union disappeared until the end of the sixteenth century.

The mission of the papal legate, Father Antonio Possevino, to Ivan IV, had been intended to draw Moscow into the union, and its failure caused the papacy to concentrate its efforts on the Orthodox Church in Poland. The Ruthenian bishops' obedience to the Pope was officially announced on the 8 October 1596. The decisions of the Uniate-Catholic synod were met with numerous protests from the Orthodox clergy and nobility. The larger part of the clergy and the faithful, together with bishops remained in the Orthodox camp. Despite the failure of the Brest Synod in fully uniting Orthodox and Roman churches, new union projects concerning the Orthodox Church in Poland continued to arise prior to the end of $18^{\text {th }}$ century.

The Vatican's interest in the Orthodox Church in Central Europe was renewed at the end of the First World War. On April 1 ${ }^{\text {st }}, 1917$, the Pope created the Congregation for the Oriental Churches which was responsibile for all issues relating to the activities of all the Eastern denominations. Despite aims at unification, attempts at church union have had a negative influence on the relations between the Roman Catholic and Polish Orthodox Church in contemporary Poland. The result of centuries of attempts at unification under the Pope has been fragmentation and division.
\end{abstract}

\begin{abstract}
Streszczenie: Wyznawców Kościoła prawosławnego w Polsce wielokrotnie próbowano zmusić do przyjęcia unii kościelnej i podporządkowania się władzy papieży. Po raz pierwszy próbę taka podjęto w połowie XIII wieku, kiedy to czyniono starania pozyskania do unii księcia halicko-wołyńskiego Daniela. Ponownie unię kościelną próbowano narzucić Cerkwi prawosławnej za panowania Władysława Jagiełły. Sprawa unii kościelnej na ziemiach polskich wróciła za panowania Aleksandra Jagiellończyka. Ostatecznie, w wyników zabiegów Iwana III, odrzucającego wszelkie projekty urzeczywistnienia unii florenckiej, problem unii kościelnej nie był rozpatrywany aż do końca XVI w.

Niepowodzenie misji legata papieskiego o. Antonio Possevina mającej na celu pozyskanie Moskwy do unii kościelnej, skłoniło papiestwo do skoncentrowania swych wysiłków na Kościele prawosławnym w Rzeczypospolitej. Narzucona prawosławnym w 1596 r. unia brzeska przyniosła negatywne skutki dla Cerkwi i Rzeczypospolitej. Przy prawosławiu pozostała większa część duchowieństwa i wiernych z dwoma biskupami. Nowe projekty unijne wobec Kościoła prawosławnego w Rzeczypospolitej były podejmowane aż do końca XVIII wieku.

Zainteresowanie Watykanu Kościołem prawosławnym w Europie Środkowo-Wschodniej było pod koniec I wojny światowej. W 1917 r. papież powołał Kongregację do spraw Kościoła Wschodniego, która przejęła wszystkie sprawy związane z działalnością obrządków wschodnich. Problem unii kościelnej negatywnie zaczął wpływać na wzajemne relacje między Kościołem rzymskokatolickim i prawosławnym w Polsce. Uniatyzm nie tylko nie przywróciły jedności między Kościołem wschodnim a zachodnim a nawet ową jedność oddalił.
\end{abstract}

Słowa kluczowe: unie kościelne, Polska

Keys words: Church unions, Poland

Orthodox Christians in Poland have faced numerous attempts to force them into a union with the Roman Catholic Church, ranging from the thirteenth to the twentieth centuries. Although such attempts had as their goal the unification of Christendom, they had the opposite result - fragmentation. As a result, church unions cannot be regarded as effective in promoting ecumenism or good relations among Christian faiths.

The first attempt at a union between the Roman Catholic Church and an Orthodox Church took place as early as the mid-thirteenth century. Daniel, the duke of Volhynia and Halich (1239-1264), was encouraged to enter into a union and join the Roman Catholic Church by an emissary of Pope Innocent IV (1243-1254), the Italian Franciscan John de Piano Carpine. After consulting with bishops, igumens (abbots), and boyars, the duke refused to subject the Orthodox Church of Halich to the pope. This refusal did not end the pope's efforts to draw the Ruthenian dukes into the union, but papal missions in 1247 and 1248 were equally unsuccessful. ${ }^{1}$

The initial question of union arose from Daniel's attempts to become a crowned head of state, a king. Daniel also wanted to put one of his sons, Roman, on the Hungarian throne - and Hungary was a Roman Catholic kingdom. To achieve his goal, Daniel arranged for his son to wed Gertrude, the daughter of the Hungarian king Bela IV (12351270 ), in 1252. However, the duke found a powerful opponent to his goal in the Metropolitan Cyryl II (1247-1281),

W. Abraham, Powstanie organizacji Kościoła łacińskiego na Rusi, vol. I, Lwów, 1904, p. 120-127; S.M. Solov’ev, Istoriia Rossii s drevneshykh vremen, vol. II, Moscow, 1963, p. 334; F. Sielicki, Polsko-ruskie stosunki kulturalne do końca XV wieku, Wrocław, 1997, p. 78, 79; A. Mıрóvoßıт,

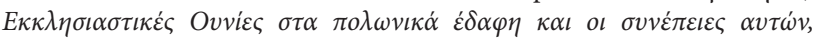
Białystok 2013, p. 3-26. 
who came from Halich Ruthenia, and played an important role in Hungarian politics. The Metropolitan had already obtained a reaffirmation of all the privileges of the Ruthenian Church and the cancellation of all tax duties on the clergy levied by the Tartar Khan. When the Metropolitan met with the Byzantine emperor John Dukas (1222-1254) and Manuel II, Patriarch of Constantinople (1244-1255), in Nicaea, there were great consequences: a breakdown in the talks regarding church union in the Ruthenian lands, the rejection of Daniel's policy [of ties with Hungary] and the forging of new ties with Alexander Nevsky (1220-1263), the Prince of Novgorod.

The subject of church union quickly re-appeared in Cracow during a meeting between the papal legate Opizo of Mezzano and Duke Daniel. Opizo even brought the duke a crown sent by Pope Innocent IV. According to the Latopis Hipacki, Daniel did not accept it, arguing that he "could not meet an envoy on foreign ground." To meet that objection, the legate followed the duke to Kholm, but it was not until December 1253 that Daniel met with Opizo in Drohiczyn, where the duke, his son Lev (1264-1301), and the Mazovian duke Siemowit were preparing for war against the Yotvingians (Jatvingians). Daniel assented to the coronation - to take place in the church in Drohiczyn - in return for Rome's help in the war against the Tartars.

During the coronation, Opizo's attempted to draw Daniel into a church union, but the papal legate failed. ${ }^{2}$ Political conflicts with Roman Catholic states - Hungary, Poland [duke of Cracow Leszek the White (1194-1227)], and the Teutonic Knights' Order - led the Orthodox clergy to oppose a closer relationship with the Church of Rome. The leaders of the Orthodox Church, and especially Metropolitan Cyryl II, whose opinion Daniel had to consider, stood firmly against any union. ${ }^{3}$

During the reign of George I, duke of Halich (13011315), Pope John XXII (1315-1334) hoped to use the good relations between George I and the Polish king Ladislaŭ the Elbow-High (Władysław Łokietek) to submit the Halich metropolitanate to the pope in Avignon, strengthening John XXII's faction in the growing dispute over leadership of the Roman Catholic Church. The Pope addressed a bull to the duke Boleslav - George II, duke of Halich (13151340), encouraged the duke to join the Roman Catholic Church. The pope sent a second envoy in 1327 and he tried to persuade the Polish king to influence the Ruthenian duke of Halich to come back to the Latin church. ${ }^{4}$ However, the Pope's request was rejected; Ladislaŭ the Elbow-High understood the religious situation in Ruthenia and did not want to encourage such conversions.

\footnotetext{
H. Paszkiewicz, Z życia politycznego Mazowsza w XIII w., [in:] Księga ku czci profesora Oskara Haleckiego, Lwów 1935, p. 203-228.

3 Makarii, Metropolitan of Moscow, Istoriia Russkoi Tserkvi, kn. 3, part 1, Moscow, 1995, p. 332-333; W. Abraham, Powstanie organizacji Kościoła łacińskiego na Rusi, Lwów, 1904, p. 121-143; E. Golubinskii, Istoriia Russkoi Tserkvi, vol. II, Moscow, 1900, p. 82-86.

4 A. Theiner, Vetera Monumenta Poloniae et Lithuaniae gentiumque finitimarum historiam illustrantia, vol. I, Rome, 1860, v. I, p. 383, 384; M. Hrushevs'kyi, Istoria Ukrainy-Rusy, vol. III, Kyïv, 1905, p. 134; W. Abraham, Powstanie organizacji kościoła łacińskiego na Rusi, vol. I, p. 193.
}

Another attempt at forcing the Orthodox Church into a union with Rome took place during the reign of Ladislaŭ (Władysław) II Yagiello (1386-1434), who supported uniting the churches in contrast to his predecessor. In order to achieve this aim, Yagiello wanted to use the prestige of Metropolitan Cyprian (1389-1406) and his good relations with Constantinople. During two long stays in Lithuania and the Polish kingdom, Cyprian participated in talks regarding the church union. ${ }^{5}$ The discussions resulted in a correspondence (conducted in the name of the Polish king) with the Patriarchy of Constantinople, aiming at a church union. The Metropolitan and Ladislaŭ suggested calling for an ecumenical council in one of the Ruthenian towns, which would allow a theological discussion on the form of reunion, but the patriarch was sceptical about the recommended site for the talks. ${ }^{6}$

Ladislaŭ II's suggestion was meant to reunite the Church by subjecting the Orthodox churches to the papacy. Negotiations with Cyprian were to lead to direct talks with the Patriarch beyond the control of the Holy See. The talks indicated the need for organising a council and achieving church unity by discussing the differences in the dogma and rite. In the 1390's, the king found few supporters of this concept among the Roman Catholic clergy of the Polish kingdom: the Polish episcopate preferred a policy of Catholicisation in the Ruthenian lands through the development of German and Polish settlements and the development of a Roman Catholic network of churches.

Supported by the Polish king, the Lithuanian grand duke Vitold (1392-1430) decided to reshape the Orthodox church structure in the Grand Duchy of Lithuania to bind it more closely to the Roman Catholic Church. In order to achieve this aim, a new, separate Kyïv Metropolitanate was to be created, adjusted to the boundaries of the Grand Duchy of Lithuania. The plan also foresaw that the hospodar alone would name any new Metropolitan as well as talks with bishops on church union. This plan was put into action in 1414-1415.

In 1414, Vitold banished the visiting Kyiv Metropolitan Focius (1408-1431) from Lithuania. ${ }^{7}$ At the same time, on behalf of the dukes and boyars of the Grand Duchy, he demanded that the Patriarch appoint a new Metropolitan. ${ }^{8}$ Duke Vitold presented the Patriarch with his own candi-

\footnotetext{
Makarii, Istoria Russkoi Tserkvi, vol. IV, p. 79; T. M. Trajdos, Metropolici kijowscy Cyprian i Grzegorz Camblak a problemy Cerkwi prawosławnej w państwie polsko-litewskim u schyłku XIV i pierwszej ćwierci XV w., [in:] Balcanica Posnaniensia. Acta et studia, vol. II, Poznań 1985, p. 217, 218; A. Mironowicz, Kościół prawosławny w państwie Piastów i Jagiellonów, Białystok, 2003, p.147-149.

6 A. Lewicki, Sprawa unii kościelnej za Jagiełty, „Kwartalnik Historyczny”, vol. XI (1897), p. 322; A. Prochaska, Władysław Jagiełto, vol. II, Cracow, 1908, p. 119-120; E. Golubinskii, Istoriia Russkoi Tserkvi, vol. II, Moscow, 1901, p. 338; K. Chodynicki, Kościót prawosławny a Rzeczpospolita Polska, 1370-1632, Warsaw, 1934, p. 43.

Latopis Nowogrodzki, [in:] Polnoe sobranie russkikh letopisei (PSRL), vol. III. St Petersburg, 1841, p. 105; T.M. Trajdos, Metropolici kijowscy..., p. 225; A. Mironowicz, Kościół prawosławny w państwie Piastów i Jagiellonów, p. $169-170$

8 E. Golubinskii, Istoriia Russkoi Tserkvi, vol. II, p. 369, 370; K. Chodynicki, Kościół prawosławny..., p. 36.
} 
date, Gregory Tsamblak, who was the nephew of the late Metropolitan Cyprian. Tsamblak was an outstanding Orthodox catechist, an igumen of the Serbian monastery in Kosmet, and had lived in Lithuania since $1406 .{ }^{9}$ He was also a highly respected Orthodox writer; his works were popular among the clergy as well as secular readers. Although the Patriarch rejected Vitold's demands, a synod took place in Navahrudak on 15 November 1415 under the leadership of Vitold. It elected Tsamblak to be the Metropolitan of Lithuania and Kyïv (1415-1419). ${ }^{10}$ The new metropolitan was consecrated by the bishops present at the synod.

Facing the beginning of the Roman Catholic Council of Constance (1414-1418) and increasing Roman Catholic missionary activity in the east, the bishops participating in the synod in Navahrudak had to be aware of the consequences of their decision. Both Ruthenian and Polish sources agree that the synod in Navahrudak was imposed by the Roman Catholic monarch and called simply to overthrow Focius, the defender of Orthodoxy. Its rulings were intended to weaken the Orthodox Church and subjugate its followers to the Roman Catholic Church and the Lithuanian Grand Duke. ${ }^{11}$

Promoted within the Polish king's and Lithuanian great duke's circles, the issue of church union reappeared when Tsamblak became Metropolitan. Pope John XXII was personally interested in the union and he named Ladislaŭ II as protector of the Latin Church in the east with the right to convert the Orthodox and disseminate Roman Catholic propaganda. ${ }^{12}$ The first project for union was presented in the name of the king by John Stechir at the council of Constance in January $1415 .{ }^{13}$ On 30 November 1417, Ladislaŭ II sent a report by the legates in Samogitia to the council, informing it of his and Vitold's energetic actions to win over the Orthodox. The king presented ways to make the Orthodox subject to the Holy See and described the struggle with Focius. At the same time, the Metropolitan of Kyïv Focius induced the patriarchal synod to impose an anathema on Tsamblak. For those clergy who supported the new Metropolitan, severe church punishments up to anathema were introduced. Therefore the union was only possible through the complete incorporation of the local Lithuanian Orthodox church into the Roman Catholic Church. No contacts with Constantinople took place, so the political conditions were very much different than in the times of Metropolitan Cyprian.

The only effective way of enforcing the church union was to announce it officially at the council in Constance. Ladislaŭ II was adamant in his desire to incorporate the

\footnotetext{
K. S. Mechev, Grigorii Tsamblak, Sofia, 1969, p. 15-18.

10 Ibid, p. 180; Akty, otnosiashchiesia k istorii Zapadnoi Rossii, vol. I, nos. 24/25 St. Petersburg 1846, p. 33; I. Daniłowicz, Skarbiec dyplomów papieskich, vol. II, Wilno, 1862, nr 1178, p. 44-45; K. Chodynicki, Kościót prawosławny..., p. 38-40; T. M. Trajdos, Metropolici kijowscy..., p. 224; A. Mironowicz, Kościół prawosławny w państwie Piastów i Jagiellonów, p. 170.

${ }_{11}$ T. M. Trajdos, Metropolici kijowscy..., p. 225, 226; A. Mironowicz, Kościół prawosławny w państwie Piastów i Jagiellonów, p. 171.

12 T.M. Tajdos, Metropolici kijowscy ..., p. 228

13 T. Silnicki, Sobory powszechne a Polska, Warsaw, 1962, p. 93.
}

Orthodox Church in the Polish-Lithuanian Commonwealth into the Roman Catholic church. In his letter of 1 January 1418, he congratulated Martin V on his election to the papal throne, while informing him of a delegation led by the Metropolitan Tsamblak, representing the Orthodox faithful from Lithuania, Moldavia, and the Kingdom of Poland. The Polish king stressed the Metropolitan's learning and assured the Pope that the establishment of church union was the aim of this journey. ${ }^{14}$ Tsamblak reached Constance in 1418, with six Orthodox bishops, a few presbyters, and some boyars and the delegation was granted an audience with Pope Martin V. ${ }^{15}$ Citing Ladislaŭ II's direction, Tsamblak expressed his firm conviction of the need to unite the churches, to accept papal primacy, and to reverse the schism of the eleventh century.

However, the Metropolitan made this important decision dependent on two conditions - a formal discussion in the council on dogmatic differences and the Byzantine Patriarch's and Emperor's participation in the union. ${ }^{16}$ Tsamblak's approach suggested a return to the concepts of 1396-1397, but the Byzantine emperor, Manuel II, was now unfavourably disposed towards the Latin Church. As a result of the Metropolitan's conditions, no agreement concerning the union could be reached. As a result, Ladislaŭ II's union plans could not be fulfilled, but Tsamblak had also gone to Constance at the direction of Grand Duke Vitold, who now threatened the forcible incorporation of $\mathrm{Ru}$ thenians into Roman Catholicism. ${ }^{17}$

Tsamblak's diplomatic talents told him to respect Ladislaŭ's and Vitold's instructions. Indeed, Tsamblak's dependency on the Yagiellonian dynasty was so great that he would never have been able to return to Kyïv had he implemented his own approach. He was fortunate that he managed to return from Constance without causing a breakdown in his relations with the two monarchs.

In contrast to the Ruthenian situation, the Turkish threat to Constantinople caused the Byzantine Greeks seeking military aid from the West to accept union with the Roman Catholic Church. At a council in Ferrara, and later in Florence (5 July 1439), bishops penned a treaty of union between the churches. While some of the Orthodox lords refused to sign the union treaty, others accepted it for pragmatic reasons. ${ }^{18}$ The Metropolitan of Kyïv and an igumen of the St. Dimitry Monastery in Constantinople, Isidor the Greek, also took part in the council.

Metropolitan Isidor (1437-1447), who earlier took part in the council of Basel in 1431, became a particularly ardent supporter of the concept of union. At the council in Florence, he actively supported the cause and willingly signed the council statements. As a result, he was soon appointed

\footnotetext{
14 T. M. Trajdos, Metropolici kijowscy..., p. 230.

15 J. Fijałek, Biskupstwa greckie..., p. 48-50; J. Kłoczowski, Młodsza Europa, Warsaw, 1998, p. 333.

16 A. Prochaska, Władysław Jagiełło, vol. II, Cracow, 1908, p. 397; K. Chodynicki, Kościół prawosławny..., p. 46.

17 PSRL, vol. V, p. 260; T. M. Trajdos, Metropolici kijowscy..., p. 230.

18 S. Runciman, Wielki kościół w niewoli, Warsaw, 1973, p. 116-126;

B. Gudziak, Unia florencka a metropolia kijowska, [in:] S. Stępnia, ed., Polska - Ukraina. 10000 lat sąsiedztwa Przemyśl, 1994, p. 19.
} 
cardinal and legate for the eastern European countries by Pope Eugene IV. Isidor left Rome and returned to Ruthenia, penning a letter on 5 March 1440 from Buda which informed the faithful of the union and calling for its implementation. ${ }^{19}$ For a few months in 1440, he remained in the Kingdom of Poland and the Grand Duchy of Lithuania promoting the Florence Union, but his appeals were not received with enthusiasm either by the Orthodox or by the Roman Catholic clergy. Most of the Orthodox faithful saw the union as a threat to their religious identity while the Orthodox clergy and secular magnates stood firmly against the union. As a result, the Florence Union was rejected by the Eastern Church's faithful and had no impact in Poland or Lithuania.

$* * *$

A second attempt at implementing the Florence Union in Poland came in 1474, when the Orthodox bishop of Smolensk, Misael Pstruch, became Metropolitan of Kyïv. ${ }^{20}$ Casimir the Yagiellonian (1447-1492) made acceptance of the Florence Union a condition for Pstruch's acceptance of his appointment. Pressed by the king and the papal nuncio Antonio Bonumbre, the Metropolitan allegedly sent a letter to Pope Sixtus IV (1471-1484) on 14 March 1476. In this letter, the Metropolitan expressed a willingness to join the Union, but also accused Roman Catholics of persecuting Orthodox believers although the Union had been expected to ensure understanding and peace between the Churches. In his memorial, the Metropolitan underlined that the Ruthenians showed a respect for the Pope that was equal to their respect for the patriarchs of the East. In his mind, unity with the Roman church did not mean breaking with the Patriarchate in Constantinople. The memorial was also supposedly signed by thirteen representatives of the Lithuanian and Ruthenian nobility. ${ }^{21}$

Misael's 1476 message from the Ruthenian clergy and nobility to Pope Sykstus IV is considered dubious. The original has been lost and it was only in 1605 that the Uniate Metropolitan Hipacy Pociej (1599-1613) identified a copy and had it printed. According to Rev. Jan Fijałek, Misael's letter cannot be authentic because it is written in seventeenth-century language. This scholar suspects the letter was created to support the later Union of Brest. ${ }^{22}$

The problem of church union returned in the reign of Alexander the Yagiellonian (1501-1506). Alexander became Grand Duke of Lithuania in 1492 and two years

\footnotetext{
19 M. Harasiewicz, Annales Ecclesiae Ruthenae, Leopolis, 1862, p. 77, 78; E. Golubinskii, Istoriia Russkoi Tserkvi, vol. II, p. 448, 449. For Metropolitan Isidor's activities during 1439-1440, see J. Dlugosz, Historiae Polonicae, liber XII, Opera omnia, vol. V, (ed. A. Przeździecki), Cracow, 1869 , p. 566, 578-580.

20 J. Wolff, Kniaziowie litewsko-ruscy, Warsaw, 1895, p. 669, 670.

21 W. Hryniewicz, Prekursor unijnych dążń Rusinów. Memoriał unijny metropolity Mizaela, [in:] R. Łużny, F. Ziejko i A. Kepiński, eds., Unia brzeska, geneza, dzieje i konsekwencje $w$ kulturze narodów słowiańskich Cracow,1994, p. 54-65; A. Mironowicz, Kościół prawosławny w państwie Piastów i Jagiellonów, p. 192.

22 . Fijałek, Los unii florenckiej w Wielkim Ksiestwie Litewskim za Kazimierza Jagiellończyka, „Sprawozdanie z czynności i posiedzeń Polskiej Akademii Umiejętności”, vol. XXXIX (1934), p. 23-25.
}

later, married Helena, the daughter of the Grand Duke of Muscovy, Ivan III (1462-1505), and a descendent of the last Byzantine emperor. (Her mother, Sophia Paleologus had lived in Rome after the fall of Constantinople and became Ivan III's second wife. $)^{23}$ After the marriage, there were attempts in 1499 to convince Helena to convert to Roman Catholicism. ${ }^{24}$ The Grand Duke of Moscow accused Alexander, Metropolitan Joseph of Kyïv (1492-1501), the bishop of Vilnius Wojciech Tabor (1491-1507), and Bernardine monks of forcing Helena to change her faith and of building Roman Catholic churches in areas where only the Orthodox lived. Regardless of this pressure, Helena refused to join the Latin Church. ${ }^{25}$

The new metropolitan of Kyï, Joseph Bulharynovich, a lord of Smolensk, assumed his position with the support of Alexander and was accepted in his new position by $\mathrm{Pa}$ triarch Nifont II (1497-1502) in 1500. After receiving the Patriarch's blessing, Metropolitan Joseph addressed the Pope, expressing the desire to join the union of Florence. This position was supported by Alexander who sought to have his marriage with an Orthodox princess accepted by Rome. However, Pope Alexander VI (1492-1503) demanded that the Metropolitan surrender all titles received from the Patriarch. In contrast to the Polish clergy, the Pope did not require the re-christening of Ruthenians who joined the Roman Catholic Church, but he informed Alexander (now king of Poland since 1501) that he could not accept Metropolitan Joseph under his jurisdiction because he had been consecrated by the Patriarch of Constantinople Nifont and not the Uniate Patriarch John. Joseph naturally did not accept this position. ${ }^{26}$

In any case, the Roman Catholic episcopate was more interested in developing its own church structure than in supporting the union. The Polish Catholic bishops sought to increase their influence by developing church confraternities, supporting Bernardine missions, and converting Jews and Orthodox believers; contemporary Roman Catholic theologians believed that the Orthodox could not reach salvation through their distinctive faith. ${ }^{27}$ When Ivan III rejected all projects for bringing the Florence union into practice, discussion of church union disappeared until the end of the sixteenth century.

Subjecting the Eastern Church faithful became one of the prime objectives for Rome following the Council of

\footnotetext{
23 S. M. Solov'ev, Istoriia Rossii s drevneishikh vremen, vol. III, p. 111-113; F. Sielicki, Polsko-ruskie stosunki kulturalne..., p. 112, 113.

24 W. Białowiejska, Stosunki Litwy z Moskwa w I połowie panowania Aleksandra Jagiellończyka (1492-1499), „Ateneum Wileńskie”, VII, Wilno, 1930, p. 778-781; K. Pietkiewicz, Wielkie Księstwo Litewskie pod rządami Aleksandra Jagiellończyka, Poznań, 1995, p. 166.

25 J. Garbacik, Helena, [in:] Polski Słownik Biograficzny, t. IX, Wrocław Warsaw, 1960, p. 362.

26 K. Chodynicki, Kościót prawosławny..., p. 71-72.

27 J. Fijałek, Kościół rzymskokatolicki na Litwie. Uchrześcijanienie Litwy przez Polskę i zachowanie w niej języka ludu pod koniec Rzeczypospolitej, [in:] Polska $i$ Litwa $w$ dziejowym stosunku, Cracow 1914, p. 260-264; K. Pietkiewicz, Wielkie Księstwo Litewskie..., p. 169; A. Mironowicz, Kościół prawosławny w państwie Piastów i Jagiellonów, p. 198-199.
} 
Trent (1545-1563). The mission of the papal legate, Father Antonio Possevino (1534-1611), to Ivan IV, Tsar of all the Russias (1547-1584) since 1547, had been intended to draw Moscow into the union, but its failure caused the papacy to concentrate its efforts on the Orthodox Church in Poland. The creation of the Moscow Patriarchate in 1589 was an additional impulse for this transfer of interest for Rome feared that the new Patriarch could control the Orthodox Church in Poland. Popes Pius V (1566-1572) and Klemens VIII (1592-1605) saw the union of the churches in the Kingdom of Poland and the Grand Duchy of Lithuania as a way of linking Rome with Moscow. This initiative was supported by Stefan Batory (1576-1586) and Sigismund III Vasa (1587-1632) since both monarchs supported the reforms of the Trent council and the policy of Rome towards the Orthodox church. Nuncio Possevino gave the Jesuits the task of implementing the union by preparing a synod and gaining the support of the Orthodox magnates. The preparation and the course of the synod in Brest in 1594 already led some of the Commonwealth's Orthodox inhabitants to accept Rome's spiritual leadership. ${ }^{28}$

During the Reformation in Poland during the sixteenth century, the position of the Orthodox Church was weakened when many representatives of prominent noble families converted to Protestantism and Roman Catholicism ${ }^{29}$. The internal disorganisation of the Orthodox Church also seemed to call for unification; the Orthodox hierarchy was particularly susceptible to such thinking, particularly since many of the higher clergy did not follow Orthodox canons. ${ }^{30}$ No wonder that talks on accepting the Pope's supremacy were mostly conducted with Ruthenian bishops.

The decisions of the 1594 synod had great influence on bringing the union project to life. The synod found Gideon

\footnotetext{
28 A. Ammann, Abriss der ostslawischen Kirchengeschichte, Vienna, 1950, p. 212-214; K. Chodynicki, Kościót prawosławny a Rzeczpospolita Polska. Zarys historyczny 1370-1632, Warsaw 1934, p. 204-346; O. Halecki, From Florance to Brest (1439-1596), Rome 1958, p. 367-370; M. Hrushevs'kyi, Istoriia Ukrajiny-Rusy, vol. VII, Kyïv,1909, p. 540-564; T. Kempa, Książę Konstanty Ostrogski, wojewoda kijowski i marszałek ziemi wołyńskiej, Toruń 1997, p. 119-170; M. O. Koialovich, Litovskaia Tserkovnaia uniia, vol. I, St. Petersburg, 1861, p. 150-161, 305-308; B. Kumor, Geneza i zawarcie unii brzeskiej, [in:] R. Łużny, F. Ziejko i A. Kępiński, eds., Unia brzeska, geneza, dzieje i konsekwencje $w$ kulturze narodów słowiańskich Cracow, 1994, p. 26-44; J.S. Gajek i S. Nabywaniec, eds., Unia brzeska $z$ perspektywy czterech stuleci Lublin, 1998, p. 27-56; K. Lewicki, Ksiąze Konstanty Ostrogski a unia brzeska 1596 r., Lwów, 1933; E. Likowski, Unia brzeska, Poznań, 1889, p. 67-167; Makarii, Istoriia Russkoi Tserkvi, vol. IX, St Petersburg, 1880, p. 571-590; A. Mironowicz, Wokół sporu o przyczyny unii brzeskiej, [in:] "Białoruskie Zeszyty Historyczne", nr 2 (4), Białystok 1995, p. 23-38; J. Pelesz, Geschichte der Union der ruthenischen Kirche mit Rom von den ältesten Zeiten bis auf die Gegenwart, vol. II, Würzburg-Wien 1881; A. Pekar, The Union of Brest and Attempts to Destroy it, „Analecta Ordinis S. Basilii Magni”, seria II, vol. XIV (XX), Rome 1992; S. Załęski, Jezuici w Polsce, vol. I, Lwów, 1900, p.306-317.

29 A. Mironowicz, Ours or Others. Orthodox Population in the Multi-faith and Multicultural Polish-Lithuanian Commonwealth from the 16th to the 18th Century, [in:] Das Bild Des Feindes. Konstruktion von Antagonismen und Kulturtransfer im Zeitalter der Türkenkriege. Ostmitteleuropa, Italien und Osmanisches Reich, unter redaktioneller Eckhard Leuschner und Thomas Wünsch, Berlin 2013, p. 151-162.

30 P. N. Batiushkov, Kholmskaia Rus', VII, St. Petersburg 1885, p. 106-107; A. Mironowicz, Podlaskie ośrodki i organizacje prawosławne w XVI i XVII w., Białystok, 1991, p. 107-108.
}

Balaban, bishop of L'viv (1576-1607), guilty in his conflict with the brotherhood of L'viv and Metropolitan Michael Rahoza (1588-1596) excommunicated him. In addition, many reforms were made in the inner organisation of the Church, particularly for parish schools and clerical brotherhoods. Thanks to the synod's decisions, the brotherhoods were strengthened at the cost of the bishops' powers. Dissatisfied with the Matropolitan's decisions, Cyryl Terlecki, bishop of Lutsk (1585-1596), organised a meeting in Sokal with three bishops [Balaban of L'viv, Dionizy Zbirujski of Kholm (1585-1596), Michael Kopystenski of Przemyśl (1591-1610)], where they prepared a new project for subjecting the Ruthenian Church to the papacy as well as a declaration of union. Supported by Chancellor Jan Zamoyski (1587-1605), the bishop of Lutsk Cyryl Terlecki went to Metropolitan Michael with a completed draft for an act of unification. The Metropolitan made three conditions: royal guarantees of equality between Orthodox and Roman Catholic clergy, protection of the Ruthenian bishops from the Patriarchs and their envoys, and placing the Orthodox lords in the Polish senate. ${ }^{31}$ Representatives of the Roman Catholic clergy under Lutsk's bishop, Bernard Maciejowski (1588-1600), took an active part in this stage of negotiations.

Sigismund III approved the project along with two of the Metropolitan's three conditions; the king would not grant seats in the senate to Orthodox bishops. The king argued that it was not within his powers to make such an important decision concerning the Polish-Lithuanian Commonwealth's senate. The Metropolitan and the Ruthenian bishops accepted the Polish king's position and, under the monarch's influence, the Metropolitan called for a synod to be held in Brest on 12 June 1595. The Ruthenian bishops sent two addresses, one to Pope Klemens VIII and another to King Sigismund III (1587-1632). In the first address, Ruthenian bishops asked to be taken under the Pope's guidance, but with a guarantee that they would retain the eastern liturgy and Orthodox rites. In the letter to the king, the bishops asked for royal protection and support for the union. ${ }^{32}$

Prior to these events, Hipacy Pociej and Cyril Terlecki went to Rome as plenipotentiaries of the king and Ruthenian episcopate. Upon arriving in Rome in November 1595, the Ruthenian bishops presented 32 articles prepared by the synod detailing their conditions for accepting the union. For example, they demanded Rome accept their own distinct religious tradition and identity. The Pope called for a special commission to look into these conditions. The papal commission concluded that since membership in the Roman Church is necessary for salvation, it cannot be subject to any preconditions. The Ruthenian bishops had to bow to this decision and they made a Roman Catholic profession of faith to the Pope. On the same day, the Pope issued the bull Magnus Dominu et laudabilis nimis, informing the Roman Catholic world that the Ruthenians

\footnotetext{
31 Akty Zapadnoi Rossii, vol. IV, p. 53-54.

32 Ibid. nr 68
} 
had joined the Union. ${ }^{33}$ The final formula was taken from the Tridentine creed (previously used by Pope Gregory XIII (1572-1585) in 1575 for the Greeks). The axiom extra Ecclesiam Romanam nulla salus was added by Pope Urban VIII (1623-1644) to the vows of the new Uniate bishops. ${ }^{34}$

This act did not return sacramental unity between Rome and the Orthodox Church in the Polish-Lituanian Commonwealth. As an act of canon law, the Union subjected the Commonwealth's Orthodox to papal rule. It also declared that the Orthodox had been excluded from Christianity before the union: only by accepting the Pope's jurisdiction could they receive salvation. Magnus Dominus clearly stated that the Ruthenian bishops were accepted into the Roman Catholic Church, not as a sister church, but as separate individuals entering into the Church. The act made no mention the bishop's synodal decision concerning the Union.

The expectations of the Ruthenian nobility were different, but they agreed to Rome's dictates. ${ }^{35}$ After the Ruthenian lords visited Rome, the Pope sent letters to the king and Latin episcopate asking them to help the Ruthenian bishops organise a union synod. In a proclamation of 14 June 1596, Sigismund III accordingly directed, the clergy and faithful of the Orthodox Church to call a synod, during which the unity of the Greek and Roman churches would be officially declared. On 21 August, Metropolitan Michael called for the synod to be held in Brest on 6 October $1596 .^{36}$ This synod was opposed by the Alexandrian Patriarch Melecius Pigas (1590-1601), his emissary exarch Cyril Lukarys (1596-1602), the protosingle to the patriarchal see in Constantinople Nicefor (1595-1599), and most of the Orthodox clergy and faithful. In his letter to the prince of Ostrog Constantin of 30 August 1596, Pigas called upon the clergy and faithful to reject the union. ${ }^{37}$ Nevertheless, the Orthodox party opposing the union decided to take part in the synod, asking the king to permit dissenters and the exarch Nicefor; Sigismund III agreed. The king sent his own emissaries in addition to papal legates and Jesuits to the synod. Many Ruthenian bishops took part in the pro-union synod, but only a few representatives of the clergy and the faithful.

In contrast, the anti-union opposition appeared in greater numbers. This party included the bishop of L'viv Gideon Balaban, the bishop of Przemyśl Michael Kopystenski, the exarch of the Tsarogrod [Constantinople] Patriarch Nicefor, the exarch of the Alexandrian Patriarch Cyril Lukarys, the Metropolitan of Bialograd [Bilgorod] Lukas, as well as bishops and archimandrites from other countries. The Orthodox fraction included ten archimandrites, six-

\footnotetext{
33 M. Harasimowicz, Annales Ecclesiae Ruthenae, Lwów, 1862, p. 193-194, 202-214; A. Theiner, Vetera Monumenta Poloniae et Lithuaniae, vol. III (1585-1696), Rome, 1863, p. 232-249.

34 W. Hryniewicz, Przeszłość zostawić Bogu. Unia i uniatyzm w perspektywie ekumenicznej, Opole, 1995, p.61-62.

35 Ibid, p. 66; A. Mironowicz, Kościół prawosławny w dawnej Rzeczypospolitej, p. 61.

${ }_{36}$ Arkhiv Iugo Zapadnoi Rossii, cz. I, vol. 1, nr 120, p. 501-504; Akty Zapadnoj Rossii, vol. IV, nr 100.

37 . I. I. Malyshevskii, Aleksandriiskii patriarkh Meletii Pigas i ego uczastie $w$ dielakh Russkoi Tserkvi, vol. II, Prilozheniee, p. I, Kyïv 1872, p. 28-44.
}

teen protopopes, and over 200 members from lower clergy. Most urban representatives came from Orthodox Church brotherhoods: eight from Vilnius, five from Bielsk, three from L'viv. Also present were a large group of representatives of the Orthodox nobility as well as citizens from towns and cities from 15 city districts and counties: L'viv (three representative), Vilnius (four), Bielsk, Pinsk, Brest, Podhajec, Halich, Kyïv, Skalsko, Braclav, Kamenets, Vladimir, Minsk, Slutsk i Lutsk. ${ }^{38}$

According to Orthodox canon law, the only group entitled to make decisions at the synod was the anti-union fraction. The Orthodox Church in Poland was formally under the jurisdiction of the Patriarch of Constantinople for the Ruthenian church was in ecclesiastical unity with Byzantium. Nicefor, who attended the synod, was fully competent to lead the Orthodox Church in Poland: he had received such powers in 1592 from Patriarch Jeremiah II when receiving the title of "protosingle to the patriarchal see" as the Patriarch's deputy. After the Patriarch's death, this authority was not revoked. The exarch Nicefor therefore had the right to lead local church councils in Poland, even in the presence of the Metropolitan of Kyïv. Moreover, Cyril Lukarys, who later became Patriarch of Alexandria (1602-1620), was also an exarch and possessed similar competence. In contrast, the bishops who had left the Orthodox Church and broken ties with the patriarchate had to face canonic exclusion. This argument carried great moral weight with the participants of the Orthodox council.

Moreover, Orthodox could regard the 1595 pro-union synod in Brest as improperly constituted. The participation of the clergy of different levels and the faithful was not only a custom, but the traditional law of the Orthodox Church, confirmed by the patriarchs. By rejecting the legal participation of secular elements, the pro-union synod discarded a prime rule of Orthodox Church organisation - conciliarity. ${ }^{39}$ However, the synod followed the Latin Church in believing the Union to be entirely a matter of the bishops' competence, a position that conflicted with the rules governing the Eastern Church. ${ }^{40}$

Upon arriving at the synod, the Orthodox representatives asked the Metropolitan about the order of the meeting. The Orthodox synod invited Metropolitan Michael to

\footnotetext{
38 Ekthesis albo krótkie zebranie spraw, które działy się na partykularnym tj.pomiastnym synodzie w Brześciu Litewskim, Cracow 1597, p. 334-340, 357-358; See also the latest edition of M. Broniewski, Ekthesis albo krótkie zebranie spraw, które działy się na partykularnym tj.pomiastnym synodzie w Brześciu Litewskim, edited by J. Byliński i J. Długosz, Wrocław, 1994; H. Pociej, Antirresis abo apologija przeciwko Krzysztofowi Philaletowi, który niedawno wydał książki imieniem starożytnej Rusi religiej greckiej przeciw ksiażkom o synodzie brzeskim napisanym w Roku Pańskim 1597, eds. by J. Byliński i J. Długosz, Wrocław, 1997; Dokumenta Unionis Berestensis, p. 341-344; P. Skarga, Synod brzeski i jego obrona, Cracow, 1997; A. Mironowicz, Bractwa cerkiewne w Rzeczypospolitej, Białystok 2003, p. 45-28.

39 W. Antonovich, Predislovie, [in:] Arkhiv Iugo-Zapadnoi Rossii, ch. I, vol. 4, Kyïv, 1871, p. 2; O. Lotots'kyi-Bilousenko, Ukrains'ki dzherela tserkovnoho prava, Warsaw, 1931, p. 119-120; A. Mironowicz, Kościót prawosławny $w$ dawnej Rzeczypospolitej, p. 63.

${ }^{40}$ Arkhiv Iugo-Zapadnoi Rossii, ch. I, vol. 1, Kyïv 1861, p. 509-517; Akty Zapadnoi Rossii, vol. IV, nr 106, p. 145.
} 
participate in the discussion. In response, the Metropolitan called upon the Orthodox representatives at the synod to accept the Union and participate in common discussions with the Latin clergy. Given this response and with the support of the Orthodox participants present, on 17 October 1596, protosingle Nicefor deprived those bishops who had subjected themselves to the Pope of their priestly rank and functions. The pro-union synod was notified of this decision in writing and the Orthodox participant sat as a separate council. Nicefor justified his decision by stating that the Metropolitan and the bishops had broken their oath of loyalty to the Patriarch, violated the decisions of the general councils which forbade the bishops to move from the jurisdiction of one Patriarch to another, and had taken the decision on uniting the churches without the permission of the Patriarch, even though such a decision could only be made at a general council. Exarch Nicefor further justified his decision by noting that the bishops had thrice rejected the council's call. Finally, he reminded them that the Union was created without the agreement of the clergy and the faithful ${ }^{41}$.

Nicefor's arguments were crucial for the Orthodox faithful, who sought ecclesiastical support in defending their rights. At the council, not only dependence on the Constantinopolitan patriarchate was stressed, but also its lawfulness and consistency with Eastern Church canons. The Ruthenian bishops' obedience to the Pope was officially announced on the 8 October 1596 and the following day Metropolitan Michael excommunicated the Orthodox bishops and other participants of the Orthodox council in the name of the synod. ${ }^{42}$ The decisions of the Uniate-Catholic synod were met with numerous protests from the Orthodox clergy and nobility. Both sides issued petitions to the king seeking to deprive members of the opposite side of their rank and functions.

The Orthodox council's decisions were confirmed by the Constantinople patriarchate. A provisional governing body was introduced to take the place of the Ruthenian bishops who had accepted the Union. This body included an appointed exarch, Balaban bishop of L'vov, the protosingle Cyril Lukarys, and the Rev. Constantin Ostrogski (1559-1608). The church union thus divided the Orthodox community into two groups - the Orthodox and the Uniate. This division followed neither diocesan nor administrative structures. The larger part of the clergy and the faithful, together with two Bishops - Michael Kopystenski from Przemyśl and Gedeon Balaban from L'viv - remained in the Orthodox camp. However, the decisions of the union synod were accepted by most of the formerly Orthodox hierarchy and part of the clergy. In contrast, the monastic clergy took

\footnotetext{
${ }^{41}$ A. Mironowicz, Orthodoxy and Uniatism at the End of Sixteenth Century and during the Seventeenth Century in the Polish-Lithuanian Commonwealth, [in:] Lithuania and Ruthenia. Studies of a Transcultural Communication Zone (15 $5^{\text {th }}$-18 $8^{\text {th }}$ Centuries), Edited by Stefan Rohdewald, David Frick, Stefan Wiederkehr, Harrassowitz Verlag-Wiesbaden 2007, s. 190-209.

${ }_{42}$ Ekthesis albo krótkie zebranie spraw, p. 329-376; Dokumenta Unionis Berestensis, p. 336-338.
}

an anti-union position and the secular believers followed their bishops as was the norm. This division is notable for the heavy participation of the protopopes (governors) of the L'viv and Przemyśl dioceses in the Orthodox synod..$^{43}$ Many clergymen in dioceses where the ordinaries had joined the union also stood against it. All the representatives of the Orthodox nobility from the Kingdom of Poland and the Grand Duchy of Lithuania refused the union. The Ruthenian burghers, and especially the Orthodox Church brotherhoods, unanimously supported the decisions of the Orthodox council. The peasantry, excluded from the discussion, had no expressed opinion on the subject. ${ }^{44}$

$$
* * *
$$

Despite the failure of the Brest synod in fully uniting Orthodox and Roman churches, new union projects concerning the Orthodox Church in Poland continued to arise after the reactivation of the Orthodox hierarchy by the $\mathrm{Pa}$ triarch of Jerusalem in 1620-1621. ${ }^{45}$ For example, suggestions for a new synod came forward in the parliamentary sessions of 1623, 1629, and 1636. On 3 November 1643, Pope Urban VIII sent letters to the king, the Uniate and Roman Catholic hierarchy as well as secular dignitaries, outlining the conditions of a future union ${ }^{46}$. On the same day, Urban VIII (1623-1644) sent letters to the Metropolitan Peter Mohyla (1633-1647) and castellan of Czernyhov Adam Kisiel (1639-1646): the Pope encouraged them to unite with the Roman church. ${ }^{47}$ King Ladislaŭ (Władysław) IV (1632-1648) as well as some magnates and Latin and Uniat bishops also encouraged union with Rome.

In response to the Pope's call in 1644, an anonymous union memorial was sent to the Roman Curia; Peter Mohyla and Adam Kisiel were said to be the memorial's authors. ${ }^{48}$ The authors strongly criticised the Union of Brest,

43 M. Bendza, Prawosławna diecezja przemyska $w$ latach 1596-1681. Studium historyczno-kanoniczne, Warsaw, 1982, p. 108-118.

${ }^{44}$ L. Bieńkowski, Organizacja Kościoła wschodniego w Polsce, [in:] J. Kłoczowski, ed., Kościół w Polsce. Studia nad historia Kościoła Katolickiego w Polsce, vol. II, part 2, Cracow, 1969, p. 840.

45 P. I. Orlovskii, Uchastie Zaporozgskikh kozakov $v$ vostanovlenii ierusalimskim patriarkhom Teofanom pravoslavnoi iuzhno-Russkoi tserkovnoi erarchii w 1620 g., [in:] Trudy Kievskoi-Dukhovnoi Akademii 1905 g., Kyïv, 1905, p. 648; J. Pelesz, Geschichte der Union..., vol. II, p. 145-148; Makarii, Istoriia Russkoi Tserkvi, vol. XI, p. 242-264; M. Hrushevs'kyi, Istoriia Ukrajiny-Rusy, vol. VII, p. 426-437; D. Doroshenko, Narys istorii Ukrainy, Warsaw, 1932, vol. I, p. 206-207; K. Chodynicki, Kościót prawosławny..., p. 425-429; J. Woliński, Polska i Kościół prawosławny. Zarys historyczny, Lwów, 1936, p. 72-73; W. Tomkiewicz, Cerkiew dyzunicka. W dawnej Rzeczypospolitej Polskiej 1596-1795, „Przegląd Powszechny”, vol. CIC, Kraków 1921-1922, p. 161-163; L. Bieńkowski, Organizacja Kościoła wschodniego..., p. 843-844; A. Mironowicz, Kościół prawosławny w dawnej Rzeczypospolitej, p. 80-82.

46 Monumenta Ucrainae Historica, vol. XI, Rome, 1974, p. 345-358; A. Mironowicz, Orthodoxy and Uniatism During the Seventeenth Century, [in:] Christianity in East Central Europe and Its Relations with the West and the East, Lublin 1996, p. 51-53.

47 A. Theiner, Vetera Monumenta Poloniae..., p. 425; Documenta Pontificum Romanorum, vol. I, p. 530-531.

48 The memorial was not an official document. It was published anonymously for reasons of personal safety; the authors feared the reaction of believers who opposed the union. For additional discussion on the union memorial, see A. Velykyi, Anonimnyi proekt Petra Mohyly po zedynenniu Ukrainskoi Tserkvy 1645 r., "Analecta Ordinis S. Basili 
presenting their own concept of linking the Orthodoxy with Rome. According to Mohyla, there were no essential differences between the Greek and Latin church as far as faith was concerned. The only differences separating the two churches appeared in their organisational structures and liturgical rites. The memorial treated both churches were treated as equal and apostolic. In the authors' view, the Union of Brest could not serve as a model for unity for it lacked "pure and holy intentions". The ostensible unity proclaimed at Brest had attempted to destroy the identity of the Eastern church. As a result, Mohyla's and Kisiel's project rejected the Union of Brest as a model since it broke the historical and ecclesiastical ties between the Orthodox community and Constantinople patriarchate. The basic concept underlying this memorial was the agreement of the clergy and the faithful with Rome, but without severing ties with Constantinople for it was the clergy and the faithful who were supposed to make the decision concerning union. According to the memorial's prescription, the Ruthenian church would remain an Eastern church with an unchanged liturgy. The Ruthenian Church could be subject organisationally to the Patriarch of Constantinople and indirectly to Rome. Rome's first reactions to the memorial were surprisingly positive, but ultimately the Congregation for the Propaganda of Faith in Rome recommended that the union be created according to rules set down by Rome. ${ }^{49}$ In reality, this decision meant the rejection of the memorial's approach.

This was not the last union attempt aimed at the Orthodox Church in Poland in the seventeenth century. These various union projects were invariably an element of a plan by the Polish government and Rome to take over all Orthodox bishoprics and eradicate the Orthodox church. For example, during the parliamentary session of 7 March 1667 , a constitution was drawn up, which was supposed to attract Orthodox clergymen to the union. ${ }^{50}$ Attempts at union were also made by John Casimir (1648-1668) and continued under the rule of John III Sobieski (1674-1696). However, these plans had a completely different character than those previously developed for they were political activities and should be viewed in the context of international politics. The war with Turkey and the attempts made by Rome to draw Russia into the union gave the Polish authorities a pretext for anti-Orthodox actions. It should be remembered that in 1676 the Polish-Lithuanian parliament forbade the Orthodox to contact their head, the Patriarch of Constantinople, who was subjected to the Turkish sul-

Magni", vol. VI, Rome 1963, p. 484-497; W. Hryniewicz, Unia bez zniszczenia. Memoriał unijny metropolity Piotra Mohyly (1644-1645), „Studia i dokumenty ekumeniczne”, R. IX, 1993, nr 1(31), p. 21-32; A. Mironowicz, Prawosławie i unia za panowania Jana Kazimierza, Białystok, 1997, p. 68-70; ibid, Kościót prawosławny w dawnej Rzeczypospolitej, p. 113-114.

49 E. Rykaczewski, Relacje nuncjuszów apostolskich..., vol. II, p. 286-288; A. Mironowicz, Orthodoxy and Uniatism During the 17th Century, [in:] Churches and Confessions in East Central Europe in Early Modern Times, ed. H. Łaszkiewicz, Lublin 1999, p. 74-77.

so Volumina Legum, vol. IV, Petersburg 1859, p. 437, 474; A. Mironowicz, Kościół prawosławny w dawnej Rzeczypospolitej, p. 207-208. $\tan$. To better execute the will of parliament, the Orthodox brotherhoods, previously independent, were subjected directly to bishops. ${ }^{51}$ This act was an attempt at destroying the brotherhoods which had served as the main support of the Orthodox Church and constituted the main centres of anti-Union opposition. The 1676 constitution also attempted to separate the Orthodox faithful from other Orthodox centres abroad. Warsaw's policy towards the Orthodox Church was also influenced by the king's conviction that by enlarging the union he could gain Russia's support against Turkey. The Roman Curia made similar attempts at the same time suggesting a religious union in Russia. Pope Innocent XI (1676-1689) appealed to the Polish king, queen, secular lords, and clergy to take action against the schismatics. ${ }^{52}$

Indeed, the Roman Curia transformed its policy regarding the Orthodox believers in Polish Ruthenia. It did not permit common Uniate-Orthodox synods which were supposed to lead to general union. Instead the existing union's enlargement was to be carried out by convincing local lords or placing Catholic-friendly bishops in Orthodox sees. The bishop of L'viv, Joseph Szumalski (1676-1700), secretly joined the Union in 1677. Two years earlier, he had been charged by John III Sobieski with administering the metropolitanate.

The union issue reappeared during the parliamentary session in 1681. The Orthodox were effectively represented only by the bishop of Lutsk, Gideon Czetwertynski (1663-1684), because the remaining two bishops were only formally "of the Greek faith". During the session, Joseph Szumalski and bishop of Przemyśl, Innocenty Winnicki (1679-1691), formally repeated the Roman Catholic creed in Warsaw's royal chapel..$^{53}$ On 27 March 1681, both bishops sent a letter to the Pope in which they assured him that they accepted his primacy and the dogmas of the Roman Catholic church.

When the Kyï metropolitanate was subjected to the Patriarch of Moscow (1685) and incorporated into Muscovy's state structure, through the Treaty of Grzymaltow, 1686, the papacy and Polish authorities aimed to destroy completely the Orthodox church in Poland, fearing that they would now become allies of Moscow. It was assumed that all Orthodox lords in the Commonwealth would join the Uniate Church. To achieve this aim, all Orthodox bishoprics were to be taken over by crypto-Uniates. Under

\footnotetext{
51 Volumina Legum, vol. V, p. 180. The consequences of the departure from a policy of tolerance were successive constitutional parliaments discriminating against non-Roman Catholics. For example, there were acts prohibiting conversion from Catholicism (1668), excluding nonCatholics from becoming nobles (1673), as well as from deputy chambers and the more important official positions $(1718,1736,1764)$. For more details, see: J. Kłoczowski, L. Müllerowa, J. Skarbek, Zarys dziejów Kościoła katolickiego w Polsce, Cracow 1986, p. 104-109; W. A. Serczyk, Unia brzeska - refleksje o tolerancji, [in:] T. Stegner, ed., Unia brzeska i jej następstwa. Materiały z sesji naukowej..., Gdańsk, 1991; A. Mironowicz, Prawosławie i unia $w$ dziejach narodu białoruskiego, „Przegląd Wschodni”, vol. XII, no.. 2 (46), Warszawa 2012, p. 275-309.

52 Documenta Pontificium Romanorum, vol. I, p. 631-634.

53 Monumenta Ucrainae Historica, vol. IV, p. 107; A. Mironowicz, Kościót prawosławny w dawnej Rzeczypospolitej, p. 225-226.
} 
the authorities' pressure, the bishop of L'viv Joseph Szumlański officially accepted the Pope's jurisdiction in 1700. Two years later, the bishop of Lutsk, Dionizy Zabokrzycki (1695-1702), did the same. Along with the lords, many monasteries and parishes joined the union under official pressure. For example, the Brotherhood of L'viv accepted the Uniate bishop's dominion in 1702. When three bishops joined the Union, the Orthodox church in the Polish-Lithuanian Commonwealth was reduced to a single Belorusan bishopric, in Mahiliou ${ }^{54}$. This state of affairs remained unchanged until the Commonwealth's fall in 1795.

$$
* * *
$$

The Vatican's interest in the Orthodox Church in Central Europe was renewed at the end of the First World War. On 1 April 1917, the Pope created the Congregation for the Oriental Churches (Congregatio pro Ecclesiis Orientalibus) which was given responsibility for all issues relating to the activities of all the Eastern denominations. In 1925, the Pro Russia commission was formed within this congregation and a Jesuit centre for the training of Eastern rite missionaries was created in Innsbruck. A similar centre was formed at the Roman Catholic University in Saltsburg. In 1930, the Pro Russia comission was separated from the congregation and reported straight to the Pope. The commission took control over missionary activity among Russians, especially those living outside the Soviet Union and including Russians living in Poland.

Along with the new Eastern policy of the Vatican, Polish bishops prepared plans for missionary activity among Orthodox believers in the new Polish state erected after World War I. In 1923, the bishop of Podlahia, Henryk Przeździecki, (initiated these activities and he travelled to Rome with a plan for popularize a Catholic Church of the Bizantine-Slavic rite in Poland. On 21 January 1924, Pope Pius XI granted Bishop Przeździecki the right to form Uniate parishes "wherever the people demand." This right was stretched to the Latin dioceses on the eastern rim of Poland - Lublin, Lutsk, Pinsk, and Vilnius. This region and the bishopric of Podhalia became the target of unionist activities in Poland. ${ }^{55}$

The new Byzantine-Slavic rite accepted and completely preserved the distinct rituals of the Eastern Church, while accepting the Pope as head of the Church, adding the filioque to church dogma, and introducing a few Roman Catholic holidays to the liturgical calendar. The synodal Russian rite [not sure what is meant here] was adjusted to Catholic dogmatics. Church Slavonic remained the litur-

\footnotetext{
54 See: A. Mironowicz, Diecezja białoruska $w$ XVII i XVIII wieku, Białystok 2008.

55 Z. Waszkiewicz, Neounia - nieudany eksperyment?, [in:] St. Alexandrowicz and T. Kempa, eds., Czterechsetlecie zawarcia unii brzeskiej 1596-1996 Toruń, 1998, p. 128-129; F. Rzemieniuk, Kościół katolicki obrząku bizantyjsko-słowiańskiego. Neounia, Lublin, 1999, p. 57; A. Mironowicz, Neounia w II Rzeczypospolitej, [in:] Kościół Greckokatolicki na Warmii i Mazurach, ed. M. Melnyka, Olsztyn 2006, p. 11-16; ibid., Neounija wo Wtoroj Rieczi Pospolitoj, „Seminarium Hortus Humanitatis”, vol. XV, Riga 2008, p. 64-66.
}

gical language, but sermons were given in the vernacular Russian, Ukrainian, Belarussian or Polish. The appearance of Byzantine-Slavic rite churches and liturgical vestments remained unchanged from their Orthodox past. The Pope's instructions stated that until a separate church hierarchy was created, the clergy and faithful of this new rite would be subject to the local Latin Church authorities. The Pope suggested spreading the neo-Uniate rite through missionary and charity activities. It was assumed that missionary work with Orthodox believers, based on the completely new rite, would be effective in winning them over to the Pope. ${ }^{56}$

In 1930, a Lithuanian priest, Francis Buczys, Superior General of the Marian order, was consecrated as the new bishop of the Byzantine-Slavic rite. To address any needs of the new union in Poland, the Pope appointed a new Apostolic Visitor, the Rev. Mikołaj Czarnecki in 1931. The new bishop, who was Ukrainian, belonged to the Eastern branch of the Redemptorist order. ${ }^{57}$ The Roman Catholic episcopate supported the new rite's development in Poland. The bishops of the eastern Latin dioceses (Lublin, Lutsk, Pinsk, Podlahia and Vilnius) in particular spoke out strongly in favour of missionary activity. Special periodicals were issued to popularize the new union - "Oriens" in Polish, "Khristianin" and "K soedineniiu" in Russian, "Kitezh" and "Da zlucheninia" in Byelorussian. ${ }^{58}$ The action of converting Orthodox believers in Volhynia was supported by the Roman Catholic press, such as "Życie Katolickie" (issued by the Roman Catholic curia in Lutsk) and "Przegląd Katolicki".

The results of the new union action were unimpressive when compared to the efforts and resources devoted to it. According to the Ministry of Religious Denominations and Public Enlightenment, in 1927 there were twenty-eight neo-Uniate parishes, thirty clergymen, and 17,000 faithful. In 1935, official Roman Catholic Church statistics listed thirty-two diocese clergymen, twenty-six monks, thirty-two alumni of the Seminar in Dubin, forty-five parishes, and 18,000 faithful. On the other hand, ministry statistics list forty-three parishes and 17,000 believers for $1938 .^{59}$ In the opinion of the Polish Ministry of the Interior, the number of neo-Uniate parishes cited by the Church had been enlarged for propaganda. According to recent data, the number of followers in the Byzantine-Slavic rite in 1930 equaled 14,443, in $1934-15,960$, and in $1939-$ $16,649 .{ }^{60}$ In fact, the overall number of neo-Uniats ranged from 17,000 to 18,000 and was not greater than the number of Uniates who converted to Orthodoxy during this

\footnotetext{
56 B. Łomacz, Praca duszpasterska duchowieństwa neounickiego, „Novum” 1980, nr 5, p. 95-103; A. Mironowicz, Kościół prawosławny na ziemiach polskich w XIX i XX wieku, Białystok 2005, p. 141-147.

57 A. Svitich, Pravoslavnaia Tserkov'w Pol'she i ee avtokefaliia, Buenos Aires, 1959, p. 194

58 M. Papieżyńska-Turek, Między tradycją a rzeczywistością, p. 410; A. Mironowicz, The Orthodox Church in Poland, Supraśl 2005, p. 45.

59 Archiwum Akt Nowych, Ministerstwo Wyznań Religijnych i Oświecenia Publicznego, 381, k. 169, 320; M. Pirożyński, Statystyka Kościoła w Polsce, Lublin, 1935, p. 16-17; Z. Waszkiewicz, Neounia, p. 142-143.

${ }^{60}$ Ibid., p. 138-139; A. Mironowicz, The Orthodox Church in Poland, p. 46.
} 
period. The problem of the new union as well as the conflicts connected with it ended with the beginning of the Second World War ${ }^{61}$.

$$
* * *
$$

After the Second World War very few Uniate parishes remained under the jurisdiction of Latin bishops, due to boundary changes. It was only after 1989 that the Uniates separated from the Latin church structure in Poland. Two Greek Catholic dioceses of the Ukrainian rite were created by the Pope and given wide autonomy within the Roman Catholic church. As a result, Uniate hierarchy and clergy were able to demand the return of some church properties. With the $400^{\text {th }}$ anniversary of the Brest Council, the Union of Brest and its consequences for the Christian community returned in academic literature.

Despite aims of unification, attempts at church union has had a negative influence on the relations between the Roman Catholic and Polish Orthodox Churches in contemporary Poland. The Roman Catholic side disregards the negative effects of union projects for the Church and Poland. Neither does it seem to notice the conclusions of the

61 A. Mironowicz, L' Église orthodoxe en Pologne au XX siècle, [in:] $L$ 'Eglise orthodoxe en Europe orientale au XX siècle, sous la direction de Christine Chaillot, Paris 2009, p. 229-248.
Commission for Ecumenical Dialogue held in Balamand, Lebanon, in 1993. That commission concluded that all forms of Uniatism not only failed to restore unity between the Churches but caused even further fragmentation. As a result, the Uniate experience cannot be an example for ecumenical dialogue between churches ${ }^{62}$.

When insisting on the conversion to Roman Catholicism of people who are already Christians, either individually or in groups, it is difficult to distinguish Uniatism from simple proselytism. As a result, Uniatism and proselytism from other Christian faiths remains a source of division and conflict among Christian denominations. Poland's experience with attempts at unification of the Orthodox and Roman Catholic Churches demonstrates that attempts to subjugate the Orthodox to the Popes did not lead to unity between Churches but became the reason for new religious and social conflicts. Church unions in Poland, because of their aims and consequences, have not been accepted in the modern ecumenical movement. The conclusion of centuries of attempts at unification under the Pope has been fragmentation and division.

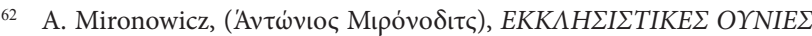

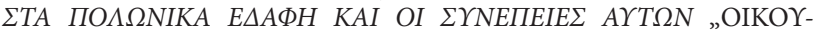

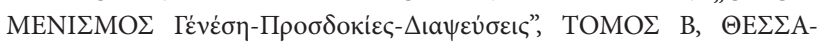
$\Lambda$ ONIKH 2009, p. 743-767. 